\title{
Original Research Paper \\ Effect of Room Temperature and Length of Exposure to recover quality DNA from Earphone Swab-Derived 126bp and 143bp Mitochondrial DNA at D-loop region
}

Ahmad Yudianto ${ }^{\mathbf{a}, \mathbf{b}, \mathbf{d}}$, Lecturer

Simon Martin Manyanza Nzilibilii, ${ }^{a,}$, MSc. Forensic Science Student

Forensic Science Program, Post Graduate School, Airlangga University, Surabaya - Indonesia.

Department of Forensic and Medico-legal, Faculty of Medicine, Airlangga University, Surabaya - Indonesia

Ministry of Health, Community Development, Gender Elderly and Children, Dodoma - Tanzania.

Human Genetic Laboratory, Institute of Tropical Disease, Airlangga University, Surabaya - Indonesia.

\section{ABSTRACT :}

Introduction: Exploration of crime scene devices left over and its surrounding is of significance in forensic identification. The significance is due to its association and/or potential harbor of biological evidence; ie., blood, blood spots, semen patches, vaginal swabs, buccal swabs, bones, or trace evidence. Such harboring of evidence from humankind proposes traceability under Locard's principle of contact.

Materials and Methods : Processing of cerumen expelled or traces logged from the 30 used earphones were subjected to 0, 1 , 7, 14 and 20 days room temperature exposure.

Results : Length of exposure has a significant effect on decreasing the level of DNA steadily. Visualization of the results of PCR on 143bp (HVS I, nt 16268-16410) mtDNA D-loop region showed a positive (+) detection only for day 1 (4 [66.67\%] samples) and day 7 (3[50\%] samples). Visualization of the results of PCR on the 126bp (HVS II, nt 34-159) mtDNA D-loop region showed a positive (+) detection only for day 1 (2 [33.37\%] of samples) and day 7 (6 [100\%] of samples).

Conclusion: In conclusion, the length of exposure to room temperature has an effect on the quality of earphone swab-derived DNA. Decreased levels of earphone swab-derived DNA showed a significance value (p\&lt;0.005) with regard to the effect of room temperature exposure

\section{Corresponding Author}

Ahmad Yudianto

Lecturer

Forensic Science Program, Postgraduate School, Airlangga

University, 4-6 Airlangga Rd., 60286 Surabaya, Indonesia

Contact : +6281330198281

E-mail : yudiyn6sby@yahoo.co.id
Article History:

Received: 2 December 2018

Received in revised form: 2 January 2019

Accepted on: 2 January 2019

Available online: 1 June 2019

KEYWORDS : DNA quality, Ear phone swabs, Forensic Evidence, Mitochondrial DNA, Room temperature

\section{INTRODUCTION :}

Identification by means of Deoxyribonucleic Acid (DNA) analysis is modern and referred as primary independent preferred technical method ${ }^{[1,2]}$. The profile accuracy is by its stability inside biological cells of samples like blood, semen, hairs and even organ hence making it suitable for isolation of the inquired ${ }^{[3]}$. Traces of this biological evidence is either free disperse of the criminal environment or found logged and harbored in objects/devices lastly used and left at the scene by the perpetrator or victim ${ }^{[4-6]}$. Such objects and devices include headsets or earphones. The association to the identification of crime perpetrator or victim and exoneration of innocent through these audio electronic devices is due to a user-contact theory supported by Locard's principle of material exchange ${ }^{[7]}$. During its use in mobile phones, player voices or as hearing aid to contact with expelled cerumen or degrading body cells which may yield DNA profile ${ }^{[8-9]}$. The devices have gained innovative progress in forensic to yield biological sample and/or traces for generation of genetic profiles during investigative tasks of the reality. However, the results of DNA analysis quality on the generated profile are interfered by a number of environmental factors including room temperature ${ }^{[10-11]}$. One alternative taken by forensic DNA experts to deal with this condition is the use of a mini- primer set ${ }^{[12-13]}$. The technique is carried out by using a method of reducing the size of Short Tandem Repeat (STR) assays in the examination of the locus of the nuclear $\mathrm{DNA}^{[14]}$ and reducing the size of hypervariable segment [HVS] 1 or 2 of mitochondrial DNA (mtDNA), which is used as amplification products $^{[15]}$. The use and sequencing of mtDNA in forensic identification are based on ability to determine the genetic relationship, thus 
expediting the process of individualization especially in cases involving a large number of individuals such as mass disaster [16]. Specificity of mtDNA in genetic relation is by a contained non-coding region, the displacement loop (D-Loop) at positions 16024-576 of nucleotides (nt). This region is also called the control region since it is a segment that contains the elements of the replication origin, transcription initiation, and regulators ${ }^{[17]}$ .While acknowledging the techniques to handle samples impacted by environment, there remains a need to understand such effect on samples logged to earphone. This study, therefore, experimented association of room temperature on the effect of room temperature on the quality of earphones swabderived mitochondrial DNA.

\section{MATERIALS AND METHODS :}

A total of 30 samples of earphone swab derived DNA was taken from respondents who agreed and signed a written informed consent. This consent was of a voluntary participation in the scholarly study aimed at knowledge exploration and contribution to the scientific community through findings sharing and publication. This scholarly aim with the purpose in understanding the effect of room temperature on samples logged to earphones as evidence that would be found at crime scene. As also, the study didn't fragment harmful content rather than the quality and trend of mtDNA on D-loop from the earphone swab derived sample. Hence, therefore, the intent preserved and refrained from profiling for personal and individualized identification.

\section{Experimentation protocol :}

The materials for DNA extraction were DNAzol reagent (Invitrogen, Thermo Fisher Scientific, Waltham, MA, USA) and 70\% ethanol (EMSURE®, Merck KGaA 64271 Darmstadt, Germany). The material for Polymerase Chain Reactions (PCR) were PCR mix -12.5 $\mu$ l (Promega Corporation, Madison, USA) comprising of dNTPs (ATP, CTP, TTP GTP), MgCl2, Taq polymerase and Nuclease-free water; mtDNA primers - 143bp (HVS I, nt 16268-16410) A F D I L 5' C A C TA G G ATA C $\begin{array}{lllllllllll}\mathrm{C} & \mathrm{A} & \mathrm{A} & \mathrm{C} & \mathrm{A} & \mathrm{A} & \mathrm{A} & \mathrm{C} & \mathrm{C} & 3 & \text {, and }\end{array}$ 5'GAGGATGGTCAAGGGAC3' ${ }^{[18]}$, 126bp (HVS II, nt 34-

AFDIL 5'TCTCCAAGCGGGTGGTGCATTTA3' and 5'AAATAATAGGCAGGAGAGGATATC3'[15].

Then extraction and isolation of DNA were performed. Laboratory processing was conducted at $26.5^{\circ} \mathrm{C}$. Positive control $(\mathrm{K}+)$ was used to control findings. Other measures included the use of sterile supply, material, and equipment, assigning a code to every sample, use of protective gears to prevent contamination, calibrated of machines together laboratory room sterilization and disinfection by Ultraviolet lamps.Room Temperature exposure on the level of earphone swab derived DNA Exposition of earphone samples was conducted at $28.5^{\circ} \mathrm{C}$ to $30^{\circ} \mathrm{C}$ of room temperature from 0,1 , 7, 14 to 20 days.

Polymerase Chain Reaction amplification and electrophoresis visualization

Cell lysed and isolated during extraction produced DNA template for PCR processing. The template under this study was polymerized and amplified using two hypervariable segments: (HVS) II (126bp, nt 34-159) and HVS I (143bp, nt 16268-16410) of D-Loop region of the mtDNA as shown in Figure 2 to Figure 5.

Results of the DNA sample extracted were measured for DNA 1 e vels and purit y b y u s ing U l t r a violet - vis ib 1 e Spectrophotometer (UV-1601, PC, Shimadzu, Japan).

\section{RESULTS :}

The measured average concentration levels of DNA are presented in Table 1.

Table 1: Amount of mtDNA isolated from earphone samples at varied exposure interval.

\begin{tabular}{|c|c|c|c|}
\hline $\begin{array}{l}\text { Iarphone } \\
\text { (samples) }\end{array}$ & moom temperature & $(\mu \mathrm{g} m) \pm S D$ & $\begin{array}{l}\text { Temperature } \\
\text { range }\left({ }^{\circ} \mathrm{C}\right)\end{array}$ \\
\hline 30 & Day 0 & $152.89 \pm 85.71$ & $28.5 \cdot 30$ \\
\hline 30 & Day 1 & $11.19 \perp 5.58$ & $28.5 \cdot 30$ \\
\hline 30 & Day 7 & $2.15 \perp 0.81$ & $28.5-30$ \\
\hline 30 & Day 14 & $0.93+0.79$ & $28.5-30$ \\
\hline 30 & Day 20 & $0.16+0.42$ & $28.5-30$ \\
\hline
\end{tabular}

Table 1 measurements portray a decreasing effect of DNA concentration from day 1 to the twentieth day as referred to a non- exposed sample of day zero. A reference at day zero measured levels of DNA at 152.89 then decreased to 11.19 after a twenty-four hours room temperature exposure, on seventh-day measurement dropped to 2.15 , then to 0.93 and lastly to 0.16 on fourteenth and twentieth respectively. Decreasing trend of DNA levels is appreciated and visualized in Figure 1, in which a sharp drop is experienced on the first day then a gradual decrease is observed steadily to twentieth.

\section{3bp and 126bp mtDNA amplicon profiling at day 1 and 7}

Profile analysis using 143bp and 126bp resulted in a band contrast formed and presented in Figure 2. Amplification and visualization of samples exposed by day one and seven became positively detected under the two primers (143bp and 126bp). Though both positively detected, band of two samples appeared with fainted contrast under 126bp after seven days of exposure as observed in Figure 2.

\section{3bp mtDNA amplicon electrophoresis of day 1, 7, 14 and}

20

Under 2\% agarose gel electrophoresis 143bp DNA amplicon, day 1 present positive $[+]$ detection of two samples with fainted bands and other 2 samples demonstrated a negative [-] detection while in day 7 samples there were 3 with negative [-] 
detection (no band displayed) and there was only one sample that showed a positive [+] detection with a faint band too. Amplification and electrophoresis of samples by 143bp (HVS I, nt 16268-16410) D-loop mitochondrial DNA amplicon on day 14 and 20 using 2\% agarose gel found that all samples displayed no band or negative detection as shown in Figure 4.

126bp mtDNA amplicon electrophoresis of day 7, 14 and 20

Amplification and electrophoretic visualization of $126 \mathrm{bp}$ mitochondrial DNA amplicon using $2 \%$ agarose gel on PCR swabbed earphone products exposed at 7, 14, and 20 intervals displayed variably. Day 7 exposed sample amplification gave a positive $[+]$ contrast detection, bands were visible for the mtDNA as shown is presented in Figure 5. Contrary to day seven, amplification and electrophoresis of samples exposed for 14 and 20 days resulted into a no display of band contrast hence a negative [-] detection.

Figure 1: The trend of effects of the length of exposure on the mean of earphone swab derived DNA.

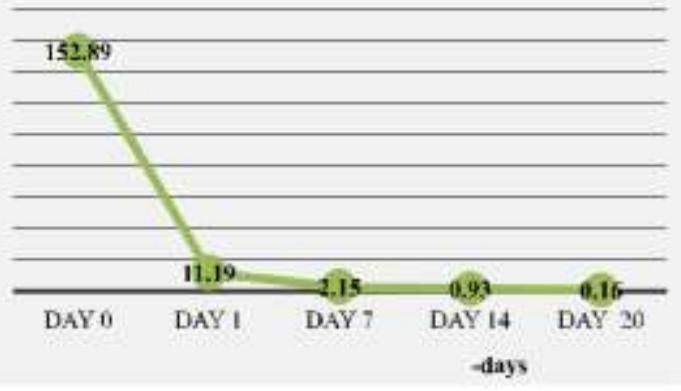

The measured mean levels of DNA as presented in Table 1 portray a decreasing effect of DNA. Extracted genetic material from less exposed earphone swabbed samples present before day seven evidence an elevated tabulation while a lowered graphical presentation and even gradual to those with maximized exposition. The graph confirms a sharp drop as sample get exposed to interfering factor (room temperature) - suggested by immediate cell lysis while in-vitro then the immediate destruction of primary DNA molecules hence a gradual damage continue steadily as interval persist. This trend supports the finding that the ability to profile DNA from environmental subjected sample gets diminishing with times, and in this case, the chance for identification of an individual by mtDNA Dloop profile get narrowed.

\section{Relative extent effect of exposition on day 1, 7, 14 and 20}

A representation of six samples for general percentage effect according to analysis is summarized in Table 2 and presented in Figure 6. The results show that, detection of the effects of room temperature exposure on earphone swab-derived 143bp (HVS I, nt 16268-16410) and 126bp (HVS II, nt 34-159) mtDNA D-loop region depend also on the exposure interval and the D-loop specific region between the two (143bp and 126bp). Day one exposition analysis, 66.67\% (4) of samples were positively detected at 143bp (HVS I, nt 16268)16410) Dloop region while $33.37 \%$ (2) were negatively detected similarly to those positively detected at 126bp (HVS II, nt 34-

D-Loop region hence a v-like tabulation (day one graph) in Figure 6. On day 7;50\% (3) of samples were detected at 143bp (HVS I, nt 16268-16410) D-loop region and 100\% (6) of samples detected at 126bp (HVS II, nt 34-159) D-loop region. Day 14 and 20, visualized a zero percentage of DNA positive detection due to exposure effect to room temperature on all earphone swab samples (143-bp (HVS I, nt 16268 16410) and 126bp (HVS II, nt 34-159) D-loop region). Relative tabulation and data presentation are referred to in Figure 6 and Table 2 respectively.

Figure 2: Electrophoretic visualization of 143-bp and 126bp PCR products of earphone swab samples $(M=$ marker, H1\&amp; H7=samples at day 1 and 7)

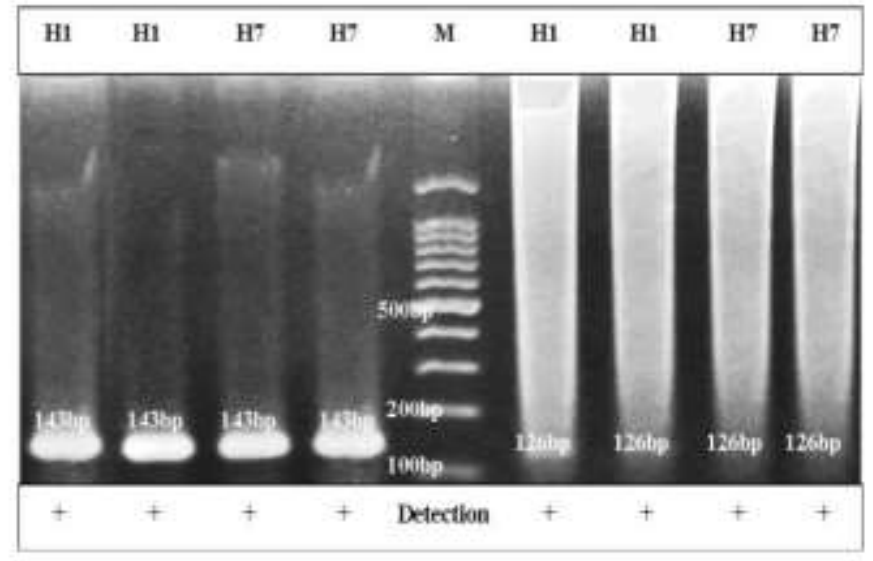

Figure 3: Electrophoretic visualization of 143-bp PCR products of arphone swab samples $(M=$ marker, H1\&amp; H7 = samples at day 1 and 7)

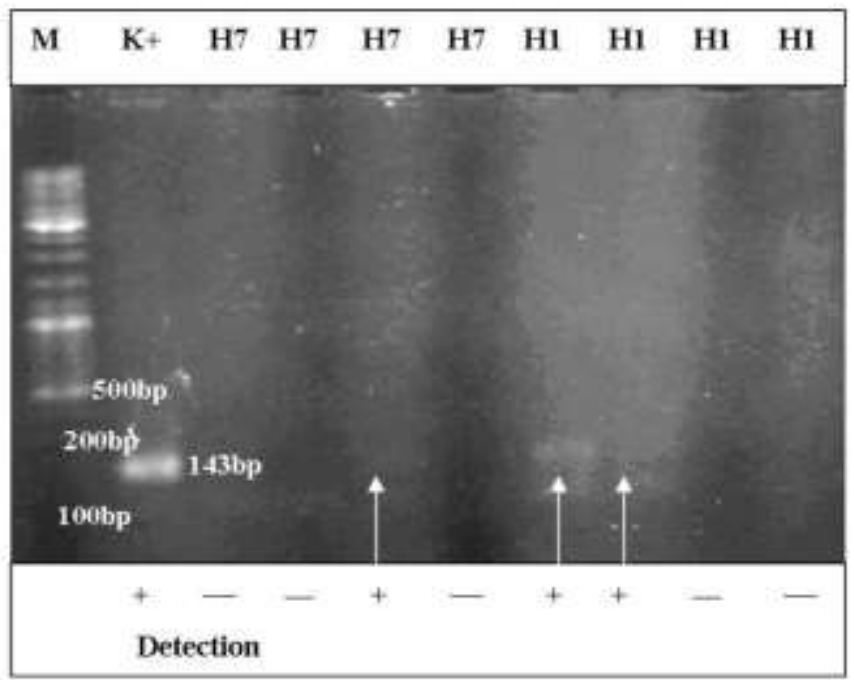


Figure 4: Electrophoretic visualization of 143-bp PCR products of earphone swab samples $(M=$ marker, $\mathrm{H14 \&}$ H20 = samples at day 14 and 20

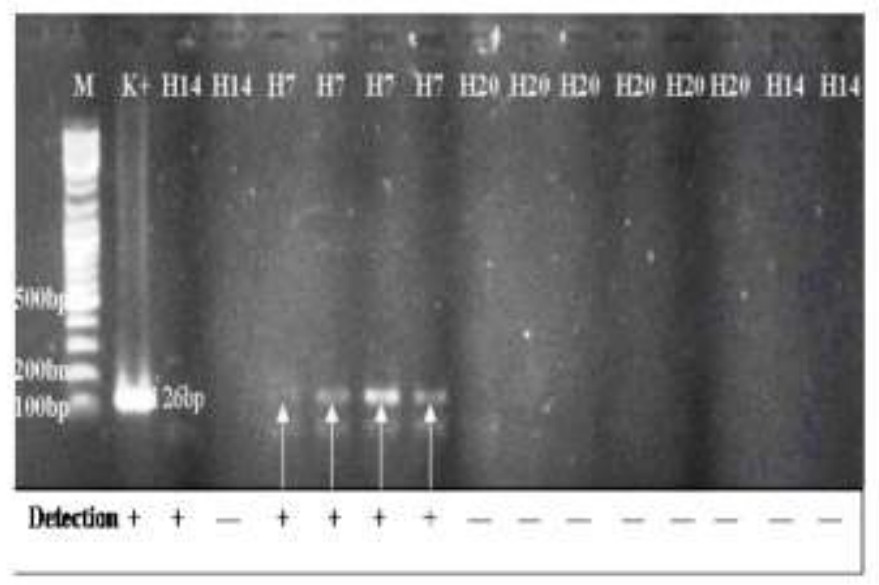

Figure 5: Visualization of 126-bp PCR products of earphone swab samples $(M=$ marker, $\mathrm{H7}, \mathrm{H14} \& \mathrm{H20}=$ samples at day 7, 14 and 20)

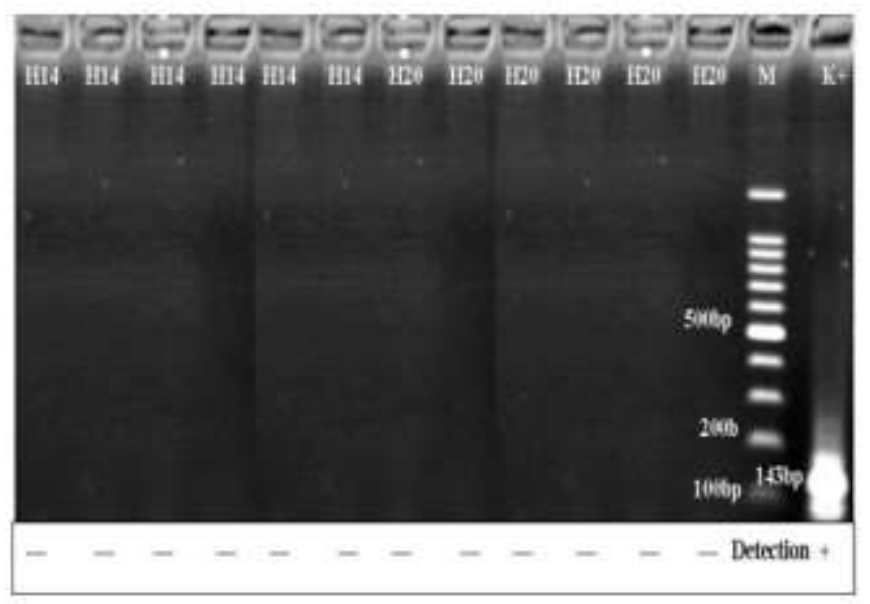

This relative presentation of six samples for general effect according to analysis is a summary of Table 2 . The results show that, detection of the effects of room temperature exposure on earphone swab-derived 143bp (HVS I, nt 16268-16410) and 126bp (HVS II, nt 34-159) mtDNA D-loop region depend also on the exposure interval and the D-loop specific region between the two (143bp and 126bp). Day one detection relativity, $66.67 \%$ (4) of samples were positively detected at 143bp (HVS I, nt 16268-16410) D-loop region while 33.37\%

were negatively detected similarly to those positively detected at 126bp (HVS II, nt 34-159) D-Loop region hence a v-like tabulation (day one graphs). On day 7; 50\% (3) of samples were detected at 143bp (HVS I, nt 16268-16410) D-loop region and $100 \%$ (6) of samples detected at 126bp (HVS II, nt 34-159) Dloop region. Day 14 and 20, visualized a null percentage of DNA detection from all earphone samples at 143-bp (HVS I, nt 16268-16410) and 126bp (HVS II, nt 34159) D-loop region).

Figure 6: Relative comparison of detection of earphone swab-derived 143-bp and 126-bp mtDNA D-loop region under room temperature

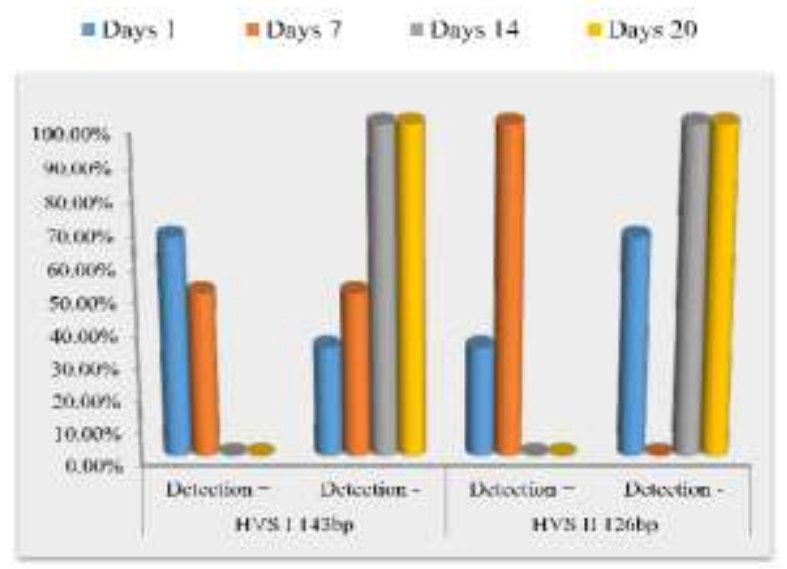

This relative presentation of six samples for general effect according to analysis is a summary of Table 2 . The results show that, detection of the effects of room temperature exposure on earphone swab-derived 143bp (HVS I, nt 16268)16410) and 126bp (HVS II, nt 34 159) mtDNA D-loop region depend also on the exposure interval and the D-loop specific region between the two (143bp and 126bp). Day one detection relativity, $66.67 \%$ (4) of samples were positively detected at 143bp (HVS I, nt 16268)16410) D-loop region while $33.37 \%$ (2) were negatively detected similarly to those positively detected at $126 \mathrm{bp}$ (HVS II, nt

159) D-Loop region hence a v-like tabulation (day one graphs). On day 7; 50\% (3) of samples were detected at 143bp (HVS I, nt 16268)16410) D-loop region and 100\%

(6) of samples detected at 126bp (HVS II, nt 34-159) D-loop region. Day 14 and 20, visualized a null percentage of DNA detection from all earphone samples at 143-bp (HVS

I, nt 16268)16410) and 126bp (HVS II, nt 34 159) D-loop region).

Table 2:

swab-derised 14:3-hp (TVS I, nt 16268-16410) and 126-bp (ITSS II, nt 34-159) matDNA D-loup region.

\begin{tabular}{|c|c|c|c|c|}
\hline \multirow[t]{2}{*}{$\begin{array}{l}\text { Bxposure } \\
\text { Intecrval }\end{array}$} & \multicolumn{2}{|c|}{$\begin{array}{l}\text { HVS I 143bp } \\
\text { nt: } 16268-16410\end{array}$} & \multicolumn{2}{|c|}{$\begin{array}{l}\text { HVS II 126bp } \\
\text { nt } 34-159\end{array}$} \\
\hline & $\begin{array}{l}\text { Detectioe } \\
(+)\end{array}$ & $\begin{array}{l}\text { Detection } \\
(-)\end{array}$ & $\begin{array}{l}\text { Detection } \\
(+)\end{array}$ & $\begin{array}{l}\text { Detoction } \\
(-)\end{array}$ \\
\hline Dens 1 & $4(6.6,7 \%)$ & $2(33,3 \%)$ & $2(33,34)$ & $4666,37 \%$ \\
\hline Days 7 & $3(50 \%)$ & $3(50 \%$ ) & $6\left(100^{\circ}=\right)$ & $0[0 \%)$ \\
\hline Days 14 & $\left.0\left(0^{*}\right)^{\prime}\right)$ & $6(100 \%)$ & $\mathrm{G}_{2}(0 \%)$ & $6(1009)$ \\
\hline Days 20 & $0\left(0^{6}\right.$ in & $6(100 \%)$ & $O_{4}\left(\%_{i}\right)$ & $69(100 \%)$ \\
\hline
\end{tabular}




\section{RESULTS OF SAMPLE SEQUENCING :}

Samples that remained to show a positive [+] detection were subjected to an analysis of sequencing for effects of exposure to room temperature. 143bp (HVS I, nt 16268-16410) and 126bp (HVS II, nt34 159) mitochondrial DNA D-loop fragments derived from earphone swab samples were sequenced using the Sanger dideoxy method by means of an Automatic DNA Sequencer based on the Dye Terminator Labeling method, protocol $^{[19]}$. The PCR product fragments sequenced were those amplified directly without cloning, a process called direct sequencing. This method was used since the process is fast and the products are the dominant nucleotide sequence of PCRamplified DNA. Primer reaction (M1 - forward) was used to determine the nucleotide sequence of 126bp and 143bp in size in the sequencing reaction. The study was capable of determining the nucleotide sequence of the mtDNA D-loop region of the samples as shown in the below; 1st_BASE_2345711_20_143_143.ab1 for day 1

NNNNNNNNGGNNNNNNNNNNNNNNANNNNGCA

TNAACCGNCAGAGCACATTA

GGGGCAGACCANNCTCGCCGCNGNANACGGGNC

NCCCGGGGAGACCAAAGNA

NCCCGNCGAGCCGGCANCTGNTGAGTCACGACC

CGAGAGGNGTGACGNCAGCC TGGGN

1st_BASE_397247_mtDNA_126bp1.ab1 for day 1

GTNGNNNTNNNNTNCTCCTTNGNNGTCCCCCGGC GCGCCCCCCTCAAGNNNNNNCTACTNGNCCTGAA TTNATTACNGCCNCCTNNTCNCNTGANTNCTGCT NCNNNANGNNNNNGCANNNNNNNNNACGNNNN NNGNNNNNGTNNANNNNNNNNNNNNNNNNNNN CNTAGTCANNNGATNGNTNCTACNNNATNNNN.

\section{DISCUSSION :}

\section{Room Temperature exposure on the level of Earphone} swab derived DNA :

DNA purity values obtained in this study were of 0.00 to 1.80 whereby the average level of DNA was $23.18 \pm 57.58 \mathrm{ng} / \mu \mathrm{l}$ in which the purity value of 0.00 indicates no DNA in the sample. These parameters of DNA are an important factor in DNA analysis, especially with regard to the successful amplification of DNA samples. DNA integrity is central to DNA forensic investigation. This implies that, despite the relatively high levels of obtained DNA as observed in findings, fragmentation or degradation may reduce its significance. Though the level of DNA required in DNA analysis varies depending on the need and type of investigation still adequate quality of DNA is also required, in which DNA should be in a minimally degraded condition as also elaborated by (1). Measurement of DNA in this study has shown a tendency of decreased levels of earphone swab- derived DNA in association with the length of exposure to room temperature (Table 1). Statistical tests were performed to determine the extent to which the length of exposure to room temperature had an effect on DNA levels. Kruskal-Wallis test and t-test of the levels of earphone swab-derived DNA on average showed a significant effect of the length of exposure to room temperature (significance value of 0000 , significance limit of $\mathrm{p} \& \mathrm{lt} ; 0.05)$. The $\mathrm{t}$-test of earphone swab-derived DNA levels showed a significance value of 0.002 and a significance limit of $p \& 1 t ; 0.05$. Thus, there is a significant difference in the levels of DNA for all of the length of exposure.

In addition to the levels of DNA sample, PCR based investigation also requires an adequate quality of DNA. In this case, degraded DNA inhibits analysis of information. Severely degraded DNA prevents the primer from annealing the target DNA replication $(20,21)$. According to (22) , adequate visualization requires adequate DNA purity and DNA levels for successful investigation including identification and paternity test. Exogenous factors of DNA degradation are in several types either, $(23,24)$. Type I degradation is in which DNA is usually degraded slowly by chemical processes for a relatively long period of time. Type II degradation is in which DNA is rapidly degraded by moisture, sunlight and even extremely high temperatures. Results of the study complement with the impact suggested in type II, that the environmental effects of temperature and length of exposure had an effect on the levels of DNA. Results of DNA measurement by spectrophotometer showed a significant decrease in the levels of DNA samples. The dependence of PCR-based DNA investigation on adequate quality of DNA is explained in a number of parameters. As discussed and established in literature the success of PCR highly depends on several factors, such as deoxyribonucleotide triphosphates (dNTPs), oligonucleotide primers, DNA template, buffer solution, reaction cycle, and enzyme. Additionally, it depends on the technical and non-technical factors, such as contamination. A sufficient quality of DNA means that DNA should be in good condition and, if it is degraded, the degradation should be as minimum as possible. Severely degraded DNA prevents the primer from annealing the target replicated DNA. Thus, a good quality of DNA constitutes a fundamental prerequisite for the overall PCR success. This is according to review collected by Cavanaugh \&amp; Bathrick (2018) , PCR sensitivity is a function of the number of cycles and the levels and integrity of DNA.

\section{Polymerase Chain Reaction amplification and Electrophoresis visualization}

Visualization of PCR products was analyzed descriptively by 
looking at the appearance of bands according to PCR product size. Positive detection $[+]$ effects of room temperature exposure and the non-detection in the visualization of PCR products for these samples was related to DNA quality contained. DNA quality includes DNA levels, DNA purity and DNA condition state (degradation). In the present study, the average level of DNA was $0.93 \pm 0.79 \mu \mathrm{g} / \mathrm{ml}$ on day 14 and $0.16 \pm 0.42 \mu \mathrm{g} / \mathrm{ml}$ on day 20 ; the trend explains the degrading process. DNA degradation was among the causes of DNA detection failure in PCR-based DNA analysis in our study as well portrayed by Figure 4 and some bands in Figure 3 and 5 . This is consistent with (26) with regard to several possible causes for failure detection of DNA, including a minimal amount of target DNA, DNA degradation that prevents the primer from annealing, lack of DNA polymerase and PCR cycle also presence of PCR inhibitors. The failure of amplification is characterized by the absence of bands on the electrophoresis results due to lack of DNA polymerase and PCR cycle. This can be controlled by the use of PCR master mix that contains Mg 2+ and Taq DNA polymerase, dNTPs in quantities tailored to the needs of optimal PCR reaction and having a proven reliability in the current PCR reaction (27). From the article lack of cycle in a PCR reaction is controlled by optimizing the primers used for PCR while adhering to $\mathrm{Mg} 2+$ recommended concentration (should be 1.5 to $4 \mathrm{mM}$ ). An excessive concentration of $\mathrm{Mg} 2+$ causes a non-specific reaction with the presence of smear on electrophoresis. In contrary, the inadequacy of $\mathrm{Mg} 2+$ causes no amplified product or no band on the electrophoresis results as also guided in protocols (28). An excessive amount of Taq polymerase causes a smear formation (non-specific reaction) on electrophoresis, whereas inadequacy of it causes a reduced efficiency of amplification and non-appearance of bands. Trisborate-EDTA (TBE) used in decalcification of samples may serve as a PCR inhibitor. This can be avoided by using ethanol to precipitate DNA extracted/isolated. Ethanol is a potential material to separate DNA from other components during DNA extraction (29). Some findings in this study show a failure of detection in the form of failed PCR amplification of DNA. This failure can be caused by degradation or damage to DNA from the effects of the length of exposure to room temperature. Cerumen attached to earphones contains detached epithelial cells of the outer ear canal. Those epithelial cells are not protected instead of directly exposed to external factors that cause degradation to contained genetic materials, DNA. According $(30,31)$, DNA damage caused by external factors such as exposure to X-rays, chemical agents, spontaneous instability and extreme temperature will result in many types of damage, such as damage to DNA strands (both double and single strand), base damage (damage to DNA bases), sugar damage and even presence of DNA crosslink andDNA-protein crosslink. Those environmental factors lead to degraded DNA. Thisdegradation can be fast or slow, depending on the affecting factors and length of exposure. Findings of this our study shows that earphone swabs can still be used as a material for DNA analysis of mtDNA with regard to the effects of exposure to room temperature $\left(28.5^{\circ} \mathrm{C}-30^{\circ} \mathrm{C}\right)$ up to day 7 . This is in potential consideration when applied to expedite forensic identification, especially in a mass disaster or criminal cases on the crime scene with little trace evidence.

\section{Sample sequencing information derived}

The positively [+] detected samples and analyzed for nitrogenous bases forming nucleotides sequence was in response of appreciating the damaging effect extent. Room temperature for samples exposed for day- 1 and day- 7 by 143bp and 126bp mitochondrial DNA D-loop fragments derived from earphone swab under Sanger dideoxy method portrayed potential effect impacted even to those still detected positive band contrast. The derived sequence of 126bp and 143bp mtDNA amplicon from earphone swab samples showed degraded nucleotides on day 1 , as marked with ' $\mathrm{N}$ ' in generated two sequences. This symbol ' $\mathrm{N}$ ' according to the International Union of Pure and Applied Chemistry (IUPAC) is suggested to indicate the presence of ambiguities (32). Therefore a suggested room temperature effect per lapsed time interval.

\section{CONCLUSION :}

This study concludes that :

The length of exposure to room temperature has an effect on the quality of earphone swab-derived DNA.

Decreased levels of earphone swab-derived DNA showed a significance value ( $\mathrm{p} \& \mathrm{lt} ; 0.005)$ with regard to the effect of exposure to room temperature.

Visualization of the results of PCR on 143bp (HVS I, nt 16268-16410) mtDNA D-loop region showed a positive

(+) detection only for day 1 (4 [66.67\%] samples) and day 7 (3 [50\%] samples) of room temperature exposure. Meanwhile, visualization of the results of PCR on 126bp (HVS II, nt 34-159) mtDNA D-loop region showed a positive (+) detection on similar exposure interval - day 1 (2 [33.37\%] samples) and day 7 (6 [100\%] samples) of room temperature.

\section{ABBREVIATIONS :}

bp: base pair(s); D-loop: Displacement loop; DNA: Deoxyribonucleic Acid; nt: nucleotides; HVS: Hyper Variable Segments; mtDNA: mitochondrial DNA; PCR: Polymerase Chain Reactions; STR: Short-Tandem Repeat; TBE: Trisborate-EDTA. 


\section{ACKNOWLEDGEMENTS :}

We appreciate and acknowledge the participation of volunteers who spent time and got involved in provide usage to earphones as evidence. Much gratitude to Postgraduate School, Forensic and Legal medicine program and the RSDS, Human Genetic Laboratory staff and all those who aided completion of this study.

\section{Funding : None}

Conflict of Interest : No conflicting interest

\section{REFERENCES :}

Dumache R, Ciocan V, Muresan C, Enache A. Molecular DNA analysis in forensic identification. Clin Lab 2016 ;62(1-2):245-8.

Ruitberg CM, Reeder DJ, Butler JM. STRBase: a short tandem repeat DNA database for the human identity testing community. Nucleic Acids Res 2001;29(1):320-2.

International Committee of the Red Cross. Missing People, DNA Analysis and Identification of Human Remains [Internet]. 2009. 52 p. Available from: www.icrc.org/eng/resources/documents/publication/p40 10.htm

Ah Van Oorschot R, Ballantyne KN, Mitchell RJ. Forensic trace DNA: a review. Investig Genet. 2010;1:14.

Song GH, Huang FB, Gao JP, Liu ML, Pang WB, Li W Bin, et al. Effects of fluoride on DNA damage and caspasemediated apoptosis in the liver of rats. Biol Trace Elem Res. 2015;166(2):173-82.

Shaler RC. Chapter 13: The Biological Crime Scene. In: Crime Scene Forensics: A Scientific Method Approach. 2011. p. 338-73.

Byard RW, James H, Berketa J, Heath K. Locard's Principle of Exchange, Dental Examination and Fragments of Skin. J Forensic Sci. 2016;61(2):545-7.

Shokry E, Filho NRA. Insights into cerumen and application in diagnostics: Past, present and future prospective. Vol. 27, Biochemia Medica. 2017.

Seo Y, Uchiyama T, Matsuda H, Shimizu K, Takami Y, Nakayama T, et al.Mitochondrial DNA and STR typing of matter adhering to an earphone. J Forensic Sci 2002 ;47(3):605-8.

Caputo M, Bosio LA, Corach D. Long-term room temperature preservation of corpse soft tissue: an approach for tissue sample storage. Investig Genet 2011;2(1):17.

Toothman MH, Kester KM, Champagne J, Cruz TD, Street WS, Brown BL, et al. Characterization of human
DNA in environmental samples. Forensic Sci Int 2008;178(1):7-15.

Butler JM. Short tandem repeat typing technologies used in human identity testing. Biotechniques. 2007;43(4).

Hwan YL, Na YK, Myung JP, Woo IY, Shin KJ. A modified mini-primer set for analyzing mitochondrial DNA control region sequences from highly degraded forensic samples. Bio Techniques. 2008;44:555-8.

Coble MD, Butler JM. Characterization of New MiniSTR Loci to Aid Analysis of Degraded DNA. J Forensic Sci2005;50(1):1-11.

Gabriel MN, Huffine EF, Ryan JH, Holland MM, Parsons TJ. Improved MtDNA Sequence Analysis of Forensic Remains Using a "Mini-Primer Set" Amplification Strategy. Vol. 46, Journal of forensic sciences. 2001. 247-253 p.

Alvarez-Cubero MJ, Saiz M, Martinez-Gonzalez LJ, Alvarez JC, Eisenberg AJ, Budowle B, et al. Genetic identification of missing persons: DNA analysis of human remains and compromised samples. Pathobiology. 2012;79(5):228-38.

Randi E, Lucchini V. Organization and evolution of the mitochondrial DNA control region in the Avian genus alectoris. J Mol Evol 1998;47(4):449-62.

Edson SM, Ross JP, Coble MD, Parsons T, Barritt SM. Naming the Dead -Confronting the Realities of Rapid Identification of Degraded Skeletal Remains. Forensic science review. 2004;16:63-90.

Slatko BE, Albright LM, Tabor S, Ju J. DNA Sequencing by the Dideoxy Method.Curr Protoc Mol Biol 2001;1-39.

Golenberg EM, Bickel A, Weihs P. Effect of highly fragmented D N A on P C R . Nucleic Acids Res. 1996;24(24):5026-33.

Mautner ME, Caputo M, Corach D. Degraded DNA samples made informative by using superprimers. F o r e n s i c S c i I n t G e n e t S u p p l S e r 2017;6(September):e448-50.

Psifidi A, Dovas CI, Bramis G, Lazou T, Russel CL, Arsenos G, et al. Comparison of eleven methods for genomic DNA extraction suitable for large-scale wholegenome genotyping and long-term DNA banking using blood samples. PLoS One. 2015;10(1):1-18.

Kawane K, Motani K, Nagata S. DNA degradation and its defects. Cold Spring Harb Perspect Biol. 2014;6(6):1-14.

Ghosal G, Chen J. DNA damage tolerance: a doubleedged sword guarding the genome. Transl Cancer Res 2013;2(3):107-29. 
Cavanaugh SE, Bathrick AS. Direct PCR amplification of forensic touch and other challenging DNA samples: A review. Forensic Sci Int Genet. 2018;32(October 2017):40-9.

Bartlett JMS, Stirling D. A short history of the Polymerase Chain Reaction. Humana Press [Internet]. 2003;226(PCR Protocols Volumen 226 de Methods in molecular biology):545. Available from:

http://www.springerprotocols.com/Abstract/doi/10.1385

/1-59259-384-4:3\#

Lorenz TC. Polymerase Chain Reaction: Basic Protocol Plus Troubleshooting and Optimization Strategies. J Vis Exp. 2012;(63):1-15.

PCR Troubleshooting | LSR | Bio-Rad [Internet]. [cited 2018 May 14]. Available from: https://www.bio-r a d . c o m/en-id/applications - technologies / p c r - troubleshooting?ID=LUSO3HC4S

Schiffner L, Bajda EJ, Prinz M, Sebestyen J, Shaler R, Caragine T. Optimization of a simple, automatable extraction method to recover sufficient DNA from low copy number DNA samples for generation of short tandem repeat profiles. Croat Med J. 2005;46(1):578-86.

Hall A, Sims LM, Ballantyne J. Assessment of DNA damage induced by terrestrial UV irradiation of dried bloodstains: Forensic implications. Forensic Sci Int Genet. 2014;8(1).

Schuch AP, Garcia CCM, Makita K, Menck CFM. DNA damage as a biological sensor for environmental sunlight. Photochem Photobiol Sci. 2013;12(8):1259.

Swgdam. Guidelines for Mitochondrial DNA (mtDNA) Nucleotide Sequence Interpretation. Forensic Sci Commun. 200;5(2):1-5. 
